\title{
A METAMORPHOSED BASIC DYKE SWARM IN THE VICINITY OF SARQARIGSUP NUNÂ (RAVNS STORØ AREA), FISKENÆSSET, SOUTHERN WEST GREENLAND
}

\author{
Clark R. L. Friend
}

\section{Introduction}

Ancient dyke swarms have been used successfully as time markers throughout the Archaean of West Greenland, particularly in subdividing the early Archaean in the Godthåb region (McGregor, 1973). This paper describes a swarm of metamorphosed basic dykes which cut across the lithological layering and an early tectonic fabric in the Ravns Storø group of metavolcanic and plutonic rocks.

Previously only sporadic occurrences of metamorphosed basic dykes have been noted in the Fiskenæsset region. The Sarqarigsup nunâ swarm may thus have a significant part to play in the division of the events which have taken place in the area from the Frederikshåbs Isblink to Bjørnesund and perhaps even further north.

\section{Previous work}

The first description of the Ravns Storø area under the GGU mapping programme was by Windley (Windley et al., 1966), whose investigations were mainly concerned with the border relations of the metavolcanics and the gneisses.

Work by Andersen and the writer in 1970 and 1972 (Andersen \& Friend, 1973), has shown that the amphibolite belt is a complex, internally folded layer within the gneisses, and not as previously thought, preserved in a syncline on top of them. No firm evidence was found to indicate that any of the gneisses are older than the amphibolites, although the possibility of this exists in some areas.

During mapping of the nunataks in the Frederikshåbs Isblink, Dawes (1970) encountered metamorphosed dykes in two swarms. These dykes were seen to cut many of the thin amphibolite horizons in the gneisses. He did not, however, observe any that cut those amphibolites which retain clear evidence of their origin as basic pillow lavas, or the associated gneiss-amphibolite transition zone, present on the northern nunatak.

\section{Field relationships of the metamorphosed dykes}

The sequence of deformation in the Ravns Storø area has been recognised briefly as follows:

$F_{1}$ : Isoclinal, only recognised in the amphibolites as relict folds.

$F_{2}$ : Isoclinal, often found as relict fold cores; the main fabric of the belt, $S_{2}$, is parallel to the axial planes of these folds.

$F_{3}$ : Regional overturned asymmetric folds, axes plunge $S W$, axial planes strike NE-SW and dip SE. 


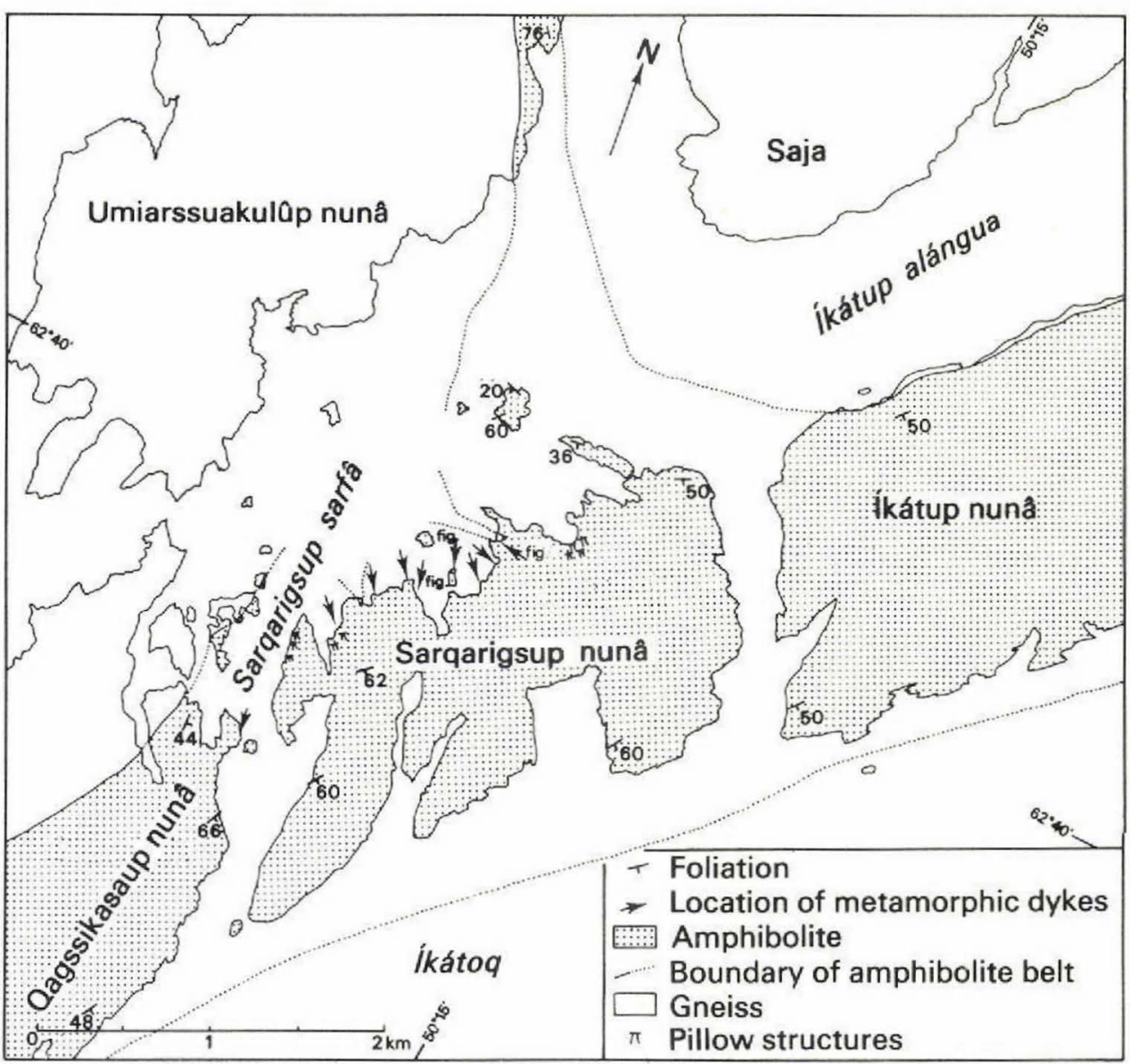

Fig. 10. Sketch map of Sarqarigsup nunâ in the Ravns Storø area showing the location of the metamorphosed dykes in relation to the boundary of the amphibolite belt.

$\mathrm{F}_{4}$ : Upright, open to close folds plunging $\mathrm{SE}$, with axial planes dipping steeply either NE or SW, striking NW-SE.

The metamorphosed dykes occur in amphibolites which are thought to be of metavolcanic origin. Layers containing recognisable pillow structures occur together with amphibolites which probably developed from more massive lavas.

The main swarm is concentrated in an area bordering the north-west coast of Sarqarigsup sarfâ (fig. 10).

The amphibolites in this part of the area are mainly highly deformed pillow lavas and magacrystic amphibolites which represent partially recrystallised and deformed gabbros (Andersen \& Friend op. cit., p. 38). The pillow lavas often show an intense foliation which is frequently affected by tight to isoclinal folds. The dykes cut across the foliation and folds in the amphibolite (fig. 11). They have then suffered later deformation which varies in character according to the angle at which they cut the foliation (fig. 12). The 


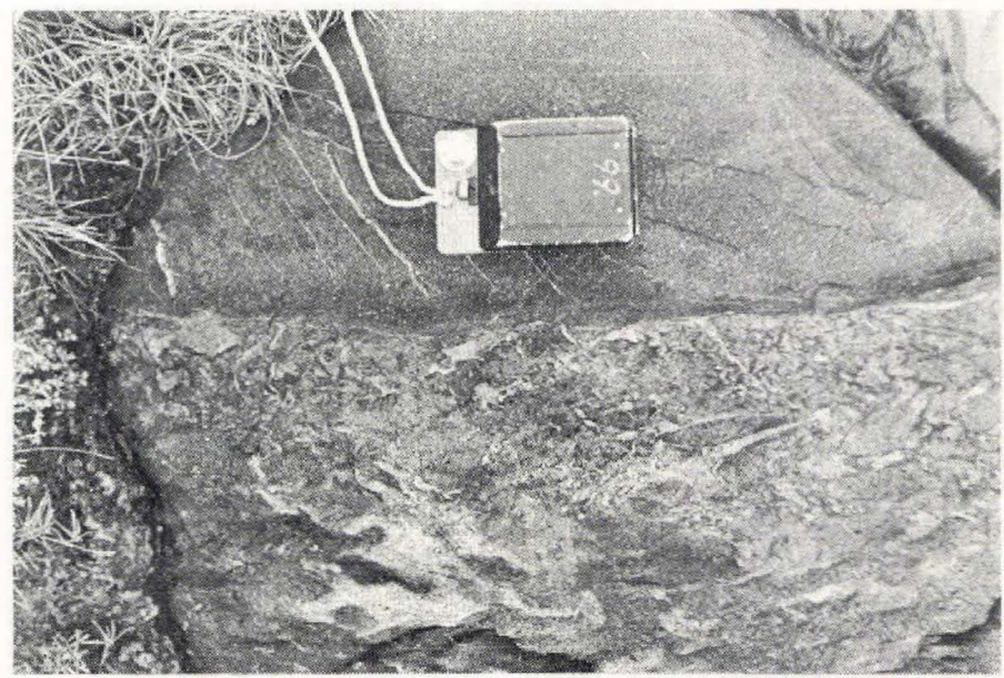

Fig. 11. Metamorphosed dyke cutting deformed pillow lavas which show the early fabric. The dyke also carries relict plagioclase phenocrysts, now seen as the white blebs, Sarqarigsup nunâ.

dykes tend to be conspicuous as they are more massive and darker coloured than the greyish amphibolites (fig. 13).

Three further dykes have been found, two on the north-east coast of Qagssikasaup nunâ, which can be considered to be part of the main swarm (fig. 10) and one more isolated dyke further north-east, at the far end of f́kátup nunâ.

\section{Descriptions of the metamorphosed dykes}

\section{Íkátup nunâ}

This dyke (GGU 129999) is $1.15 \mathrm{~m}$ thick, greyish in colour and has a weak garbenschiefer texture. It can be easily distinguished from the massive dark green metalavas which it cuts. The dyke can only be followed inland for $15 \mathrm{~m}$ but retains its thickness over this distance. It bears a resemblance to the grey amphibolites which occur immediately north-west across the strike, from which it can be distinguished by its more massive weathering, compared to the friable amphibolites which also carry staurolite.

Along the south-eastern contact of the dyke apophyses can be seen (fig. 14) which clearly demonstrate the cross-cutting relationship with the foliation planes of the metalavas. The dyke shows jointing at right angles to its margins. In contrast, the metalavas show jointing at right angles to the foliation planes which are here parallel to the lithological layering.

The dyke itself is now moderately foliated obliquely to its margins but parallel to the foliation of the metalavas, which is the dominant foliation of the belt and is believed to have developed during $\mathrm{F}_{2}$. 


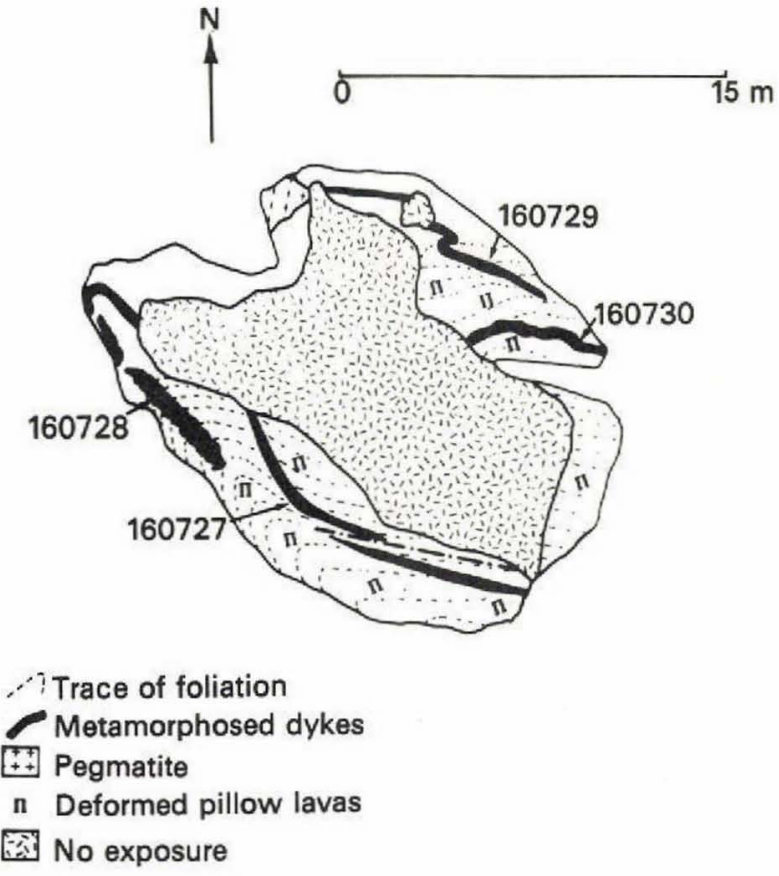

Fig. 12. Sketch map of a small island NW of Sarqarigsup nunâ with four metabasic dykes, displaying two phases of folding $\left(\mathrm{F}_{2}\right.$ and $\mathrm{F}_{4}$ ), and the varying responses of the dykes according to the angle at which they cut the $F_{1}$ foliation.

\section{Qagssikasaup nunâ}

One of the two dykes found on the north-east coast is in pillow lavas and the other in the megacrystic type of gabbroic amphibolite, the foliations of which the dykes cross obliquely.

These dykes are greenish grey in colour with hornblende enrichment along their margins. They are unusual in that they carry epidote as a major constituent.

The dyke in the gabbroic amphibolite shows joints developed obliquely to its margins and in which there has been some development of later segregational pegmatites.

This dyke has also suffered shearing parallel to the strike of the amphibolite foliation. The movement can be distinguished as being sinistral and is thought to be related to stretching due to the $\mathrm{F}_{4}$ folding. This took place on upright axial planes striking NW-SE, which is at right angles to the NE-SW striking foliation of the amphibolites. The northwest coast being on the outer arc of the fold was stretched relative to the inner arc, giving rise to sinistral slip on the foliation planes south-west of the axial plane trace.

The two dykes are relatively thin, $20-25 \mathrm{~cm}$ and thin rapidly until finally sheared out. The problem of the original thickness of the dykes has not been solved for any of the dykes discussed in this paper. The amounts of attenuation and flattening are difficult to estimate due to the lack of suitable strain markers. 


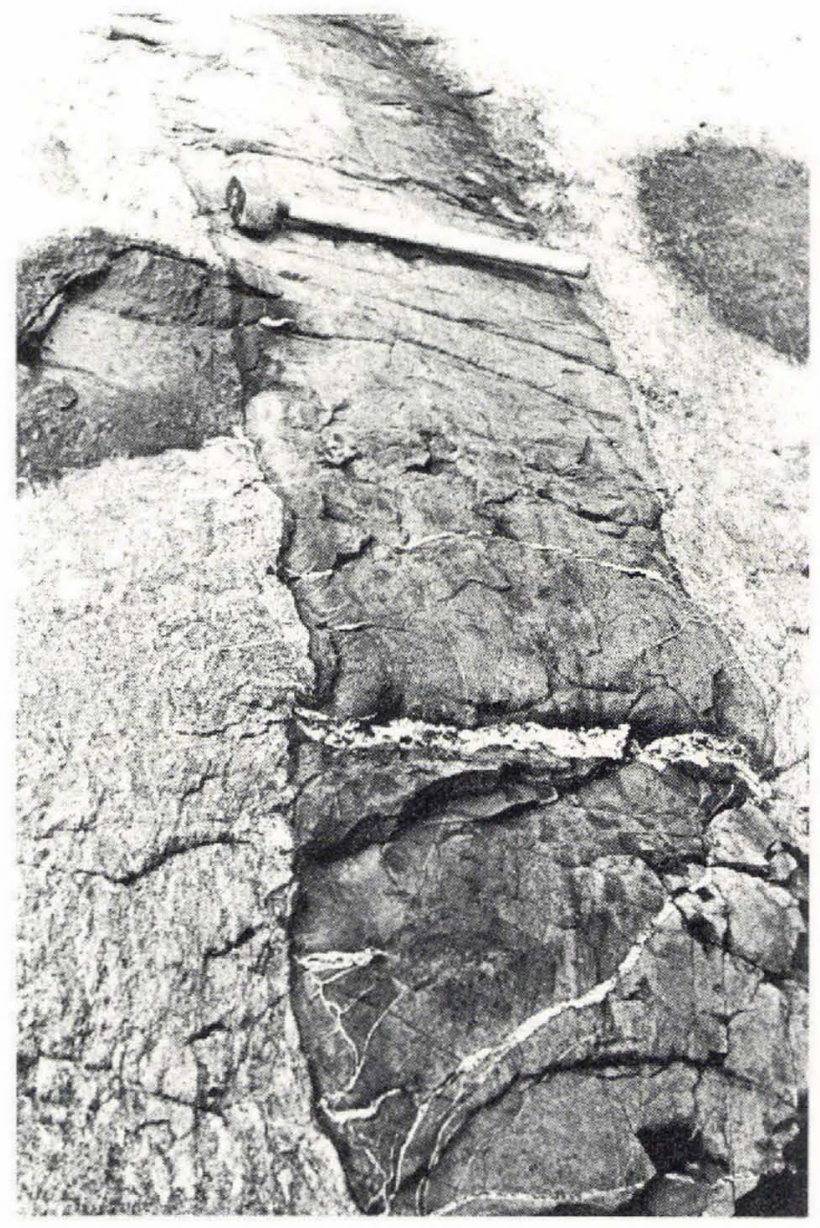

Fig. 13. Metamorphosed dyke cutting deformed pillow lavas showing the contrasting colours and lithologies. The dyke also displays later segregational pegmatites, Sarqarigsup nunâ.

\section{Sarqarigsup nunâ}

The main swarm of at least 20 dykes, varying in thickness from $2 \mathrm{~cm}$ to $1 \mathrm{~m}$, has been found on the north-west coast of the island (fig. 10). On field appearances they can be divided into three categories:

1. Massive, fine grained, greenish black.

2. Massive, fine grained, greyish.

3. Massive, medium to fine grained greyish dykes with lineated clots of hornblende.

The types 1 and 2 may have relict plagioclase phenocrysts as some dykes show 1-2 mm spots of plagioclase (fig. 11). No cross-cutting relationships with each other were observed and so it is uncertain whether or not they all belong to one phase of injection.

The pillow lavas are found in two deformational states. Firstly highly flattened as in fig. 13, and secondly as almost perfectly preserved pillow structures. It is thought that rather than two periods of pillow development the deformation is inhomogeneous, with all the pillows being approximately the same age. As the dykes cut a deformational fabric they cannot therefore be regarded as the feeders to any of the pillows. 


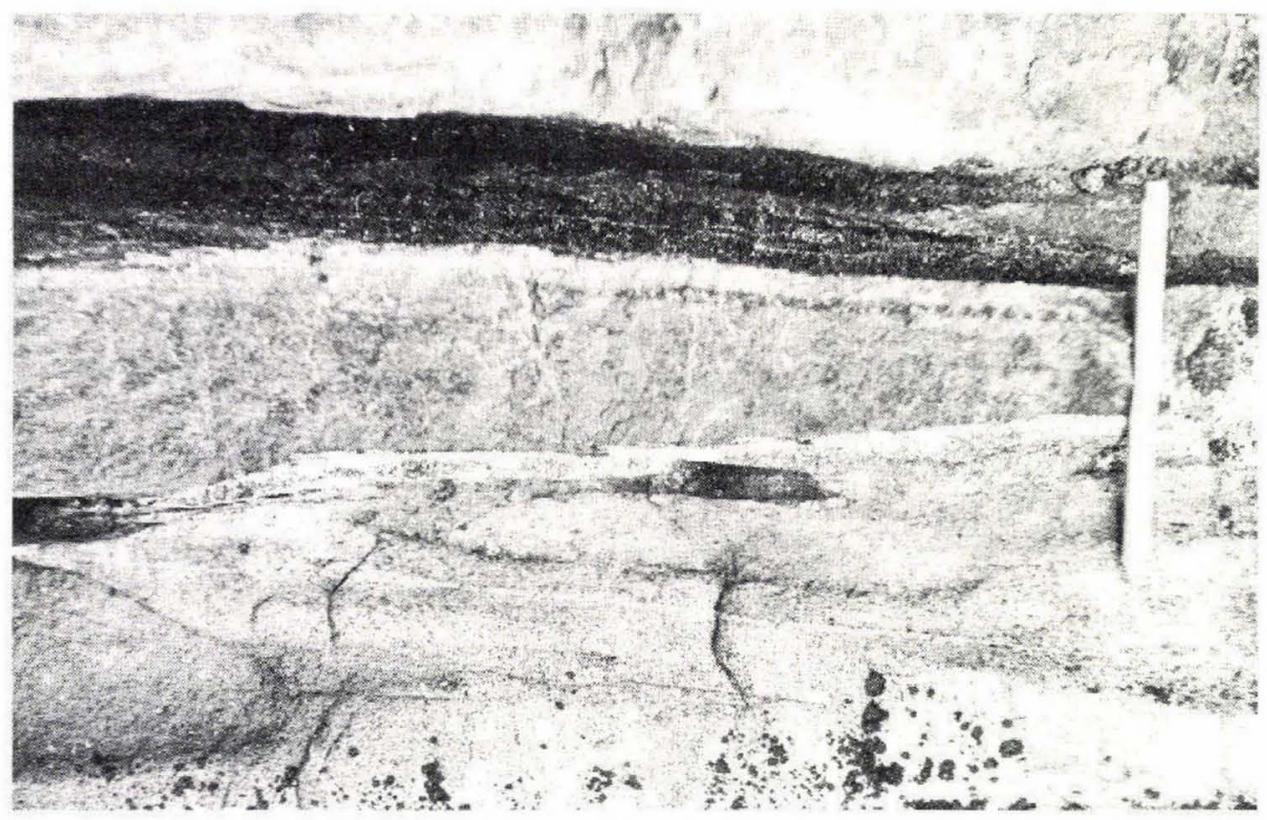

Fig. 14. Apophyses of grey metabasic dyke showing the cross cutting relationship with the foliation of the metalavas. f́kátup nunâ.

The dykes cut the $F_{1}$ foliation usually at a small angle (fig. 13) and occasionally at right angles (fig. 12). The $F_{2}$ foliation which is younger than the dykes is sub-parallel to the $F_{1}$ foliation over much of this part of the belt except at some relict fold hinges. The dykes themselves often show the $F_{2}$ foliation either sub-parallel to their margins (figs. 11 and 13) or parallel to that in the country rock.

Chilled margins can be recognised by differences in colour and in grain size; with some of the dykes showing thin dark margins due to hornblende enrichment.

Migmatitic veins are on the whole rare and where they occur appear to be due to metamorphic segregation. These veins are often in joints running across the dyke. The lack of migmatitic veins in the adjacent amphibolite is significant in this respect indicating a lithological control in their mode of development (fig. 13). The pegmatites consist dominantly of plagioclase, which forms adjacent to a hornblende rich zone in the dyke from which it is believed that the felsic material has been extracted.

In some instances the dykes have been folded into tight to isoclinal folds which have axial planes now striking NNW to NW and are believed to be of $F_{2}$ age (fig. 12). A much more open phase of folding is also displayed, which strikes ENE.

In fig. 12 dykes GGU 160727 and 160728 can be seen cutting the $F_{1}$ foliation. The dyke 160728 and the foliation are subsequently folded by $F_{2} .160727$ shows shearing parallel to the foliation planes, whilst 160728 , which is near the fold hinge and cutting the foliation at right angles shows extensive boudinage development. 


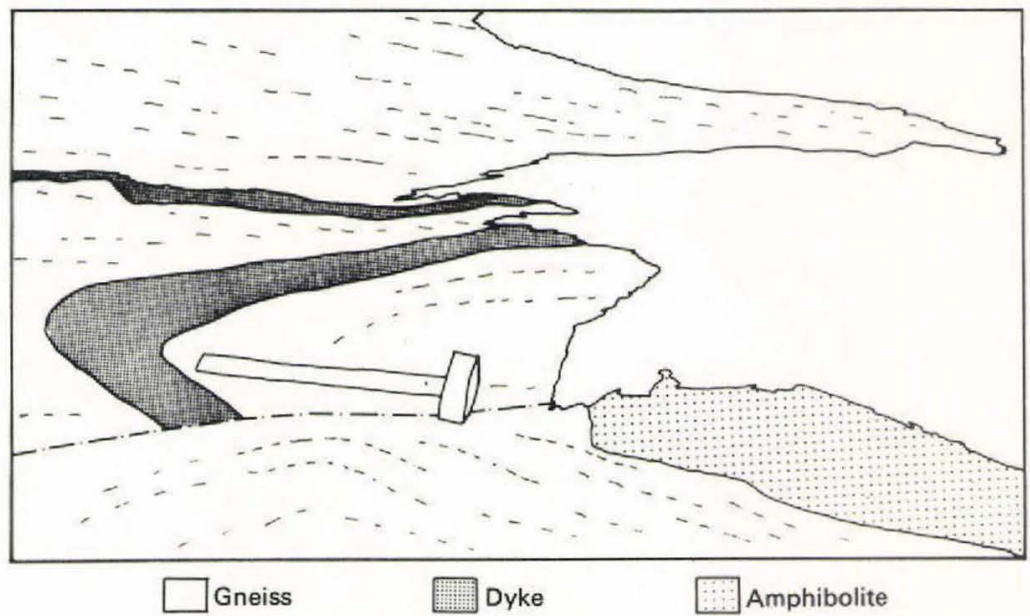

Fig. 15. Sketch from photograph of a folded metamorphosed dyke which shows $F_{2}$ folding and subsequent folding, both of which are truncated by an injected granitic gneiss. Sarqarigsup nunâ.

\section{Chronology}

The metamorphosed dykes thus fit into and help clarify the sequence of deformation:

$\mathrm{F}_{1}$ : Isoclinal folding of metavolcanics, gabbros (and gneisses?). Injection of basic dyke swarm, cutting the $F_{1}$ foliation. Injection of granitic sheets, subsequently converted to gneisses.

$F_{2}$ : Tight to isoclinal folding of the $F_{1}$ foliation and the dykes. Where dykes are in fold cores boudins develop. On the limbs dykes are sheared parallel to the foliation. Development of $\mathrm{F}_{2}$ lineation in the dykes.

Faulting.

$\mathrm{F}_{3}$ : No effects on the dykes observed in this part of the belt except for the reorientation of the $\mathrm{F}_{2}$ lineations.

$\mathrm{F}_{4}$ : Open folding of the dykes and further shearing.

These relationships can be demonstrated clearly at one locality (fig. 15). The injected granitic gneisses here are similar to the biotite gneisses found throughout the marginal area on the north-west side of the belt, particularly on Qagssikasaup nunâ and the skerries nearby, where amphibolite bands also occur. They show little or no internal structure apart from the foliation which parallels the irregular injected margin and thus resembling folding. On Qagssikasaup nunâ the gneisses are essentially concordant with the amphibolites although they do in fact truncate their lithological layering and foliation at a small angle.

\section{Petrology}

The petrology of the dykes is similar despite their varied appearences in the field. The colour of the greyer dykes is due to a higher proportion of plagioclase and that of the darker dykes to hornblende, with in one case biotite in addition.

Those dykes with white flecks can be seen to have once contained plagioclase pheno- 
crysts which have survived the deformation and metamorphic effects to be preserved as recrystallised areas of plagioclase.

The dyke on f́kátup nunâ shows little fabric in thin section. The immediate area in which it is found is relatively little affected by $F_{2}$ folds or younger as compared with the north-west coast of Sarqarigsup nunâ, where $F_{2}$ folding is strongly developed.

The main fabric of the dykes is outlined by hornblende which usually has a strong preferred orientation. Accessory minerals include apatite, zircon and opaque grains with a little quartz in some dykes.

\section{Discussion}

In his report of the mapping of the Dalagers Nunatakker, Dawes (1970) describes metabasic dykes in the gneisses. Some of the intrusive relationships he mentions (op. cit., p. 21) can be seen in those described from Sarqarigsup nunâ.

He notes that metabasic dykes cut the amphibolite layers present in the gneisses. From the mapping of Andersen, Tomas and the writer, the Ravns Stor $\varnothing$ belt can be shown to be essentially continuous with much of the amphibolite present in the gneisses, (Kalsbeek \& Myers, 1973, p. 14). If this is the case, and there is in addition reasonable evidence to equate the Dalagers Nunatakker amphibolite outcrop with the Ravns Storø group, therefore, the dykes described by Dawes appear to be about the same age as those of Sarqarigsup nunâ. On Dalagers Nunatakker the dykes cut biotite gneisses with amphibolite inclusions and these gneisses seem to have been formed from relatively little deformed granite sheets of pre-F 2 age.

It is possible that dykes were intruded over much of the region, but are now difficult to recognise because of the intensity of the deformation. It is significant that the best preserved pillow structures are found on Sarqarigsup nunâ where the metamorphosed dykes are also best preserved (fig. 10). Deformation within the region is extremely inhomogeneous, and on Sarqarigsup nunâ areas of low total deformation of $F_{2}$ age and younger are common. Over the region as a whole this is where the amphibolite belt retains its greatest original thickness. Similarly, north of Bjørnesund metamorphosed dykes are most recognisable where the anorthosite complex, of similar age to the amphibolites, is best preserved (B. J. Walton, personal communication).

The nearest metabasic dykes cutting the gneisses are on Qeqertasugssuk, about $5 \mathrm{~km}$ west of Sarqarigsup nunâ. In two cases these are amphibolites. A third dyke contains a large amount of sphene, similar to some reported by Dawes (op. cit., p. 25). This dyke however, is believed to be of a different generation being essentially a post metamorphic dolerite, possibly a MD1.

An amphibolite dyke has been found cutting the gneiss-amphibolite transition zone at the head of Majoraríssap ilua (L. S. Andersen, personal communication). This dyke does not appear to belong to the swarm described as it does not show folding of $F_{2}$ age. Otherwise no dykes have been observed cutting the transition zone, that can be attributed to the Sarqarigsup nunâ swarm. It can be shown that many of the marginal gneisses are younger than the dykes (fig. 15).

It is the recognition of the two dykes in the gneisses on Qeqertasugssuk which is the only means of identifying any gneisses that are of equivalent age to the deformed amphibolites in the Ravns Storø area, perhaps equivalent to the early gneisses of Dalagers Nunatakker. Ascertaining whether there are gneisses older than the metavolcanics would 
take a much more detailed study than is possible to present here, but the possibility is not ruled out.

The only other dyke cutting the gneisses is off the coast of Ravns Storø and is of the less basic variety as described by Dawes, having quartz as a major constituent.

Apart from the two amphibolite dykes on Qeqertasugssuk no other amphibolites which resemble metamorphosed dykes have been recognised in the Ravns Stor $\varnothing$ area.

It is proposed that the swarm of dykes forms a definitive event younger than the initial folding and metamorphism of the amphibolites, but older than the emplacement of granitic sheets, subsequently converted to gneisses.

\section{Acknowledgements}

My thanks are due to Dr. B. J. Walton for much helpful discussion. The evolution of the Ravns Storø Group has been worked out together with Lars Skov Andersen. I am also greatful to Finn Ulff-Møller and Henrik Hoffman for their assistance in the field.

\section{References}

Andersen, L. S. \& Friend, C. 1973: Structure of the Ravns Storø amphibolite belt in the Fiskenæsset region. Rapp. Grønlands geol. Unders. 51, 37-40.

Dawes, P. R. 1970: Bedrock geology of the nunataks and semi-nunataks in the Frederikshåbs Isblink area of southern West Greenland. Rapp. Granlands geol. Unders. 29, 60 pp.

Kalsbeek, F. \& Myers, J. S. 1973: The geology of the Fiskenæsset region. Rapp. Grønlands geol. Unders. 51, 5-18.

McGregor, V. R. 1973: The early Precambrian gneisses of the Godthåb district West Greenland. Phil. Trans. R. Soc. Lond. A, 272, 343-358.

Windley, B. F., Henrikson, N., Higgins, A. K., Bondesen, E. \& Jensen, S. B. 1966: Some border relations between supracrustal and infracrustal rocks in south-west Greenland. Rapp. Gronlands geol. Unders. 9, 43 pp. 